\title{
Fiscal Drag - An Automatic Stabiliser?
}

\author{
Herwig Immervoll
}

\begin{abstract}
By reducing the real value of nominally fixed tax band limits, deductions and tax credits, inflation can lead to higher real tax burdens ("fiscal drag"). The traditional view is that this reduces aggregate demand and thus acts as an automatic stabiliser. Yet, this familiar reasoning ignores the supply side and, in particular, possible effects of higher tax burdens on labour costs. Recent work on imperfect labour markets has shown that such effects can indeed arise as employees are able to bargain for higher wages that partly compensate for tax increases. In this case the resulting upwards pressure on real labour costs can be inflationary. To illustrate this mechanism, this paper analyses labour tax burdens in four European countries and how they are altered if tax systems are not adjusted for inflation. This is then combined with available results on the effects of tax changes on wages in imperfect labour markets. The results suggest that, in an unadjusted tax system, inflation can produce a moderate upward pressure on wages. It is argued, however, that more detailed empirical work on the role of taxes in the wage-setting process is needed as existing work ignores the substantial heterogeneity of workers and the tax rates they face.
\end{abstract}

JEL Classification: E31; H24; H39; D31; C81

Keywords: $\quad$ Automatic stabiliser; Inflation; Income tax;

Wage-setting; European Union; Microsimulation. 


\title{
Fiscal Drag - An Automatic Stabiliser?
}

\author{
Herwig Immervoll ${ }^{1}$
}

\section{Introduction}

Inflation can alter the structure of tax systems and, thus, the incidence and overall levels of tax revenues. There are several channels through which such distortions can operate. The most evident and thoroughly researched one is the influence of inflation on the tax schedule commonly known as "bracket creep" (Immervoll, 2005; OECD, 1986; Aaron, 1976). In the absence of offsetting adjustments, a progressive tax schedule will produce higher real tax burdens as nominal incomes rise ("fiscal drag").

The dependence of the tax system on an a priori unknown variable can be problematic. For example, inflation-induced changes by-pass the democratic process that is otherwise mandatory for enacting tax changes. On a more pragmatic level, they can lead to unintended effects that may run counter the originally intended objectives of fiscal policy. As a result, there have been numerous proposals to protect the tax system from inflationinduced distortions and many countries have, in fact, introduced automatic inflation adjustments into their tax systems (Messere, 1998; OECD, 1976; Tanzi, 1980). It has therefore been shown that any alleged practical or administrative difficulties of neutralising the effects of inflation can be overcome. However, there is one powerful economic argument that is commonly put forward in favour of inflation-induced tax increases. According to this view, increasing real tax burdens reduce consumption and thereby aggregate demand, acting as an automatic stabiliser which helps to cool down the

\footnotetext{
${ }^{1}$ This paper was written when the author was based at the University of Cambridge. He is now Economist at the OECD Directorate of Employment, Labour and Social Affairs (herwig.immervoll@,oecd.org). The paper is part of the EUROMOD project, financed by Targeted Socio-Economic Research programme of the European Commission (CT97-3060). I am grateful for access to microdata from the Finnish Income Distribution Survey (IDS) 1996 made available from Statistics Finland; the Living in Ireland Survey, 1994 (Wave 1) made available by the Economic and Social Research Institute (ESRI), Dublin; the SocioEconomic Panel Survey (SEP) made available by Statistics Netherlands through the mediation of the Netherlands Organisation for Scientific Research - Scientific Statistical Agency; and the UK Family Expenditure Survey (FES), which have been made available by the Office for National Statistics (ONS) through the Data Archive. Material from the FES is Crown Copyright and is used by permission. Neither the ONS nor the Data Archive bear any responsibility for the analysis or interpretation of the data reported here. An equivalent disclaimer applies to the other data sources and their respective providers. I am grateful for helpful comments on an earlier version of this paper from Tim Callan, Cathal O'Donoghue, Frank Wilkinson and Klaas de Vos. The views expressed in this paper as well as any errors are the author's responsibility. In particular, the paper does not represent the views of the EUROMOD consortium or the
} 
economy during inflationary spells. ${ }^{2}$ This reasoning, however, only looks at the demand side, ignoring any effects that higher tax burdens may have on the cost of production. If employees have some market power and bear less then the full burden of higher taxes then real labour costs will go up as well, generating a cost-push upwards pressure on prices and opening up the possibility of a wage-price spiral (Dernburg, 1974; Jackson, et al., 1972; Malcomson and Sartor, 1987).

During most of the 1990s, inflation has not been a major problem in OECD countries. For instance, Heinemann (2001) argues that declining inflation rates have limited the potential for employing fiscal drag as a means of increasing real tax revenues. Yet, it has been widely accepted that recent developments in Europe and, especially, the European Monetary Union (EMU), have contributed to considerable variability of inflation rates between countries. As long as there remain important structural differences between different EMU countries, one would expect a more unified monetary policy to lead to differing price developments across countries. Indeed, the process of "convergence" can itself contribute to such differences, at least temporarily (European Commission, 1999). At the same time, individual EMU countries have now arguably less control over monetary policy parameters. Smaller countries or those whose economic environment differs markedly from the EMU "average" may be particularly affected (e.g. Ireland). In this scenario, the stabilising properties of the fiscal system are of particular relevance (see Brunila et al., 2003).

The present paper aims to illustrate how inflation-induced tax distortions can affect wage levels. It builds on the recent literature explaining the consequences of changes in the level and progressivity of (effective) tax rates for the wage-setting process. In particular, I draw on results showing that changes in marginal and average tax rates influence wages in opposite directions. Using a European tax-benefit microsimulation model, I then decompose the effects of inflation-induced bracket creep into changes in marginal and average tax rates. The paper then discusses how the resulting tax changes can be used to quantify likely cost-push effects of bracket creep. The approach improves on previous

institutions to which the author is affiliated.

2 see, for instance, the model presented in Zilberfarb (1981). Nowotny (1980) reviews the macroeconomic issues. 
studies in that it is able to capture the full range of effects caused by tax changes in different parts of the population.

Section 2 reviews the channels through which taxes can influence the price level and thus provides the theoretical framework for the analysis that follows. Section 3 describes the microsimulation approach used in the empirical part of the paper. Both the model and the data are discussed here. The results are presented in Section 4 while Section 5 discusses how they can be used to approximate the impact on wage levels. Some caveats are highlighted along with possibilities to address them in future research.

\section{Theory}

The effects of labour tax burdens, whether discretionary or caused by inflation, on price levels depend on a number of factors. The most obvious is the income elasticity of demand. ${ }^{3}$ Yet, even where demand responds to changes in net incomes, tax increases may have unintended macroeconomic effects in cases where excess domestic demand is not the primary cause of inflation. If inflation is not due to domestic overheating but is "imported", curbing domestic demand is not the optimum counter measure. The same holds if price increases result from supply disturbances. Rather than inducing price adjustments, tax increases in such a situation are likely to raise the level of unemployed resources (Dernburg, 1974). Another reason why pushing up the tax burdens faced by private households may not have the desired stabilising effects is that price levels are determined by aggregate demand. As is well known, tax-financed public expenditure actually increases aggregate demand so long as the marginal propensity to consume is smaller than one. As a result, higher taxes do not translate into lower aggregate demand if lower private consumption is outweighed by increased public consumption made possible by the additional tax revenues. To prevent expansionary multiplier effects, discretionary tax increases aimed at reducing inflation have, in fact, occasionally been accompanied by measures aiming to "freeze" additional revenues. ${ }^{4}$ For non-discretionary tax increases caused by inflation, however, such attempts have not become known (it is tempting to

\footnotetext{
${ }^{3}$ Since the "bracket creep" caused by inflation are less visible than discretionary tax policy measures, there is a distinct possibility that individuals do not appreciate the full extent of tax hikes. With "fiscal illusion", demand will be less responsive to tax increases than the elasticity of demand would suggest.

${ }^{4}$ For instance, Piltz (1977), p. 175, reports that the German "Stability Law" dating from 1973 has introduced a temporary increase in the corporate income tax for the years 1973 and 1974. The law specified that resulting additional tax receipts could not be spent but had to be kept on reserve with the Bundesbank.
} 
interpret the lack of such measures as suggesting that stability considerations are not the primary reason for allowing the fiscal drag to operate).

On the supply side, the responsiveness of wages to tax burden changes is critical. In the absence of fiscal illusion, wage earners will want to compensate higher taxes by demanding wage increases from their employers. If they are successful, tax increases will lead to higher production costs and, in this case, inflation-induced tax increases in the past "may well have contributed to higher inflation rates." (Hersoug, 1984: 50)

Consider an individual subject to average tax rate $\tau_{a}$ and marginal tax rate $\tau_{m}$. With inflation $\pi$, nominal gross wages $w$ have to increase by an amount $\Delta w$. It is straightforward to show that

$$
\frac{\Delta w}{w}=\pi \cdot \frac{1-\tau_{a}}{1-\tau_{m}}
$$

For instance, consider an individual with a pre-inflation wage $w=100 ; \tau_{a}=30 \%$ and $\tau_{m}=50 \%$ and $\pi=10 \%$. This individual's nominal wage would need to increase by $\Delta w=14$ in order to keep real after-tax earnings at the original level of $70 .^{5}$

This shows that the required wage increase does not primarily depend on the magnitudes of $\tau_{a}$ and $\tau_{m}$ but on the difference between them. Note that $\left(1-\tau_{a}\right) /\left(1-\tau_{m}\right)$ is the inverse of the local progressivity measure proposed by Musgrave (Musgrave and Musgrave, 1976). The more progressive the tax schedule, the larger the additional tax burden caused by nominal wage increases (or, equivalently, by the inflation-induced erosion of the real value of tax band limits) and, thus, the larger the wage increase necessary to compensate for higher tax burdens.

To the extent that wages increase by more than inflation - even if they fall short of fully maintaining pre-inflation real after-tax income as in equation (1) - real labour costs will go up and exert upward pressure on prices. In the first instance, the macro-economic

\footnotetext{
$5(114-14 \cdot 0.5-100 \cdot 0.3) / 1.1=70$.
} 
consequence of this cost-push effect is an upwards-shift in the aggregate supply schedule.

Combined with lower aggregate demand due to higher taxes (i.e. assuming that the reduction in household demand is not undone by increased public spending), an upwardsshifting supply curve unambiguously results in lower output. The effect on the price level is less clear. It depends on the slopes of the relevant sections of the supply and demand curves. ${ }^{7}$ If aggregate demand remains unchanged (for instance, because of increased public spending), we will see both lower output and higher prices. ${ }^{8}$

But to what extent do wages actually respond to changing tax burdens? Obviously, employees must be aware of them before attempting to obtain compensatory wage increases. Without fiscal illusion, the resulting wage developments depend crucially on the structure of the labour market and, more specifically, on the wage-setting mechanism. In a perfectly competitive labour market, involuntary unemployment is ruled out and the only way labour taxes can alter the equilibrium wage level is through changes in labour supply.

This is illustrated in Figure 1. Given hourly wages $w, B_{0}$ is the individual's initial budget constraint. With a progressive tax system, the gain in after-tax income from working an additional hour declines with longer working hours (the budget constraint becomes flatter). Initially, she chooses the optimum number of working hours $h_{0}$. At the associated level of gross income $a+b$ the average tax rate is $a /(a+b)$. The marginal tax rate, illustrated by the slope of the tangency line, is $\tau_{m}$. The effects of increased tax progressivity (higher marginal tax rates but unchanged average tax rates) can be shown by changing the budget constraint to $B_{\mathrm{m}}$, reduces working hours to $h_{\mathrm{m}}$ (pure substitution effect). Conversely, lower tax progressivity (a higher average tax rates while keeping the marginal rate unchanged) would shift the budget line downwards $\left(B_{\mathrm{a}}\right){ }^{9}$ For the individual

\footnotetext{
${ }^{6}$ Whether and to what extent higher wages are, in fact, passed on to consumers in the form of price increases depends on the relative degrees of market power of producers and consumers. See Tarling and Wilkinson (1985) for a discussion of the mechanisms of mark-up pricing.

${ }^{7}$ See Blinder (1973).

${ }^{8}$ Smyth (1983) formalises these relationships in a simple model.

9 Note that it is impossible to change the average tax rate while keeping the marginal rate constant for all income levels. In Figure 1, marginal tax rates are left unchanged for all upper income levels, while for lower incomes, they are increased (right-hand part of $B_{\mathrm{a}}$ is flatter than $B_{0}$ ).
} 
with initial working hours h0, this downward shift represents a pure income effect. Assuming that leisure is a normal good, this will increase working hours (to $h_{\mathrm{a}}$ in the figure). The effects on wage levels are of course fully determined by these labour supply changes as, in a competitive labour market, wages adjust to market-clearing levels. With unchanged demand, higher marginal (average) tax rates will, ceteris paribus, therefore lead to higher (lower) wages.

\section{[FIGURE 1 ABOUT HERE]}

For most segments of existing European labour markets, however, the standard competitive model is probably unrealistic. Indeed, findings by several authors strongly suggest that there are fundamental differences in wage setting mechanisms between Europe and the US (see for instance Blanchard and Katz, 1999; Cahuc and Zylberberg, 2004). Where there is involuntary unemployment, individuals are, by definition, unable to alter their working hours freely. Hence, markets do not clear. In this situation, modern theories of imperfect labour markets offer alternative, and more differentiated, analyses of links between tax burdens and wage levels.

Starting in the mid-1980s, there have been several influential theoretical papers on how taxes impact on the wage-setting process in imperfect labour markets (Hansen, et al., 2000, Koskela, 2001, Pissarides, 1998, Sorensen, 1997; an overview is provided by Røed and Strøm, 2002, Section 4). Results from relatively recent empirical studies for a considerable number of European countries tend to be consistent with these theories indicating that the imperfect labour market model is indeed appropriate in the European context (Aronsson, et al., 1997; Graafland and Huizinga, 1996; Holmlund and Kolm, 1995; Lockwood and Manning, 1993; Malcomson and Sartor, 1987; Wulfsberg, 1996). In terms of wage formation, the focus in these models is on the respective incentives of employees and employers. That is, workers have some market power and are not seen as mere price-takers as in the competitive model.

While higher marginal tax rates lead to lower employment (and, therefore, higher equilibrium wages) in the textbook competitive scenario, a trade-off between unemployment and wage levels can explain why a more progressive tax system may turn out to be good for employment if it moderates wage demands. The focus on tax progressivity in this literature implies that it is important to analyse marginal and average 
tax rates separately. ${ }^{10}$ This is relevant in the context of the present paper as it suggests that, by analysing how inflation alters average and marginal tax burdens, it is possible to say something about the impact on wage levels.

A commonly used theoretical framework for analysing imperfect labour markets is the union bargaining model. This assumes a trade-off between unions' desire for lower unemployment among the workers they represent and higher (real after-tax) wages (Hersoug, 1984; Holmlund and Kolm, 1995; Lockwood and Manning, 1993; Malcomson and Sartor, 1987). Intuitively, by trading wages for unemployment, unions can influence wages and, thus, the slope of the budget constraint in Figure 1. Assuming constant real net unemployment benefits and unchanged progressivity at the relevant point of the tax schedule, increased average tax rates reduce the relative value of labour income vis-à-vis unemployment benefits (i.e. the replacement ratio increases). ${ }^{11}$ Unemployment thus appears less painful to union members and the union's preferences tend to shift away from avoiding unemployment towards securing higher wage increases. Increasing marginal tax rates, on the other hand, are predicted to lead to moderated wage demands, since changes in before-tax wages are now worth less in terms of union members' aftertax income. ${ }^{12}$ Note that both these predictions are contrary to those deriving from the competitive model.

The final outcome of the bargaining process is driven by the respective target wages of employers and unions as well as their relative bargaining powers. Since taxes on employment income do not change the target wage of the employer "it is not unreasonable to assume that, as long as the union has some bargaining power, the effect

\footnotetext{
${ }^{10}$ A third relevant parameter is the opportunity cost of participation in the labour market, usually represented by out-of-work benefits, and how they are affected by the tax change.

${ }^{11}$ For countries where unemployment benefits are non-taxable, a sufficient condition for the replacement ratio to increase is that benefit levels change by the same proportion as pre-tax wages (which is the case if the former is a fixed percentage of the latter). If benefits are taxable then the replacement rate will still go up if the tax system is progressive (and the inflation-induced tax increase is therefore larger for working individuals than for the unemployed whose taxable income is lower). Note also that the actual impact of the replacement rate on the wage outcome is likely to depend on the unemployment rate. See e.g. Graafland and Huizinga (1996).

${ }^{12}$ Most earlier union-bargaining models of the "right-to-manage" type take working hours per union member as exogenously given. A few more recent studies have introduced working hours as an endogenous parameter of the bargaining. See Aronsson and Sjögren (2004) and Fuest and Huber (2000).
} 
of such changes on the actual wage will be in the same direction as the effect on the union's target wage." ${ }^{13}$

While the remainder of this paper will focus on the union bargaining model, the theoretical results on the role of tax progressivity in the wage-setting process in an imperfect labour market are in line with those obtained from an alternative theoretical framework; the efficiency-wage model (Sorensen, 1997).

It is clear from the above discussion that it is essential to distinguish carefully between marginal and average tax rates when assessing possible effects of tax changes on wage levels in an imperfect labour market setting. This, however, is not straightforward for several reasons. First, tax rules are often complicated. Apparently minor details of the tax code often can cause very substantial ups and downs of people's budget constraints. Ignoring these details can seriously distort the incentives faced by employees and their representatives in the wage-setting process. Secondly, it is desirable to characterise these incentives in terms of effective tax rates by accounting for both income taxes and social insurance contributions. ${ }^{14}$ In addition, take-home pay and effective tax rates can be influenced by transfer payments as well. The rules of these benefit payments are frequently even more complicated than tax rules.

Another practical difficulty arises from the fact that different types of taxpayers face very different effective tax burdens and that, moreover, the effects of inflation on tax burdens will vary between individuals as well. Previous studies have simply computed the relevant tax rates for "typical" household types with average earnings (e.g., married couple with a single breadwinner and two children). Such an approach ignores the obvious influence of the household structure on applicable effective tax rates (number of income earners, number and ages of any dependants, etc.). Equally important, it ignores the fact that different earnings levels will be affected differently by any real-world change

\footnotetext{
${ }^{13}$ Malcomson and Sartor (1987), p. 1583. As far as the bracket creep phenomenon is concerned, this statement could be made more forcefully if social contribution schedules are not adjusted for inflation. Since contribution schedules are usually regressive, inflation potentially reduces the contribution burden faced by employers. If labour costs are indeed reduced then this further strengthens the argument that the union's target wage and actual wage outcomes can be expected to move in parallel.

${ }^{14}$ This paper assumes that unions and employers bargain over take-home pay. All mandatory social contributions are therefore considered a tax while employer contributions are disregarded. See Immervoll (2004) for effective tax rate measures including employer contributions. That paper also provides a discussion of the appropriate treatment of mandatory contributions in tax rate measures.
} 
of the tax system. Different employees therefore favour different target wages. Hence, a critical question is how unions aggregate these different preferences of the employees they represent. The resulting average preferences may be very different from one that would be optimal for someone with average earnings. ${ }^{15}$ As Lockwood and Manning, 1993 note, "the average marginal and the average average tax rates will in general not be equal to the marginal and average tax rates evaluated at the average earnings." (p. 11; italics are in the original). The choice of the most appropriate aggregation rule in practice is subject to some controversy. A method that is able to characterise the relevant parameters for all observations in a full sample of employees is attractive as it maximises analytical flexibility in this regard.

\section{Methodology: Measuring tax burdens before and after inflation}

I use a tax-benefit microsimulation model to establish how inflation alters marginal and average tax rates for each employee in representative samples of the household sector. The model contains detailed tax- and benefit rules which fully account for interactions between different instruments, such as the tax-deductibility of social insurance contribution payments or income testing of transfer payments. Using representative micro-data it also captures the heterogeneity of household types and earnings levels. The approach therefore addresses some of the potential empirical difficulties described above.

The model is used here to calculate distributions of average effective tax rates (AETRs) and marginal effective tax rates (METRs). In order to determine the effects of inflation, tax rate calculations are performed for a "before inflation" baseline corresponding to the policy rules in place in the reference year (here 1998); and a simulated "after inflation" scenario with inflated incomes (and inflated values of all other monetary amounts reported in the data, such as housing or commuting costs) but tax policy parameters, such as tax band limits, held constant in nominal terms. This simple simulation approach permits holding "everything else" constant so that changes in calculated tax rates are only due to the inflation effect of interest. Indeed, simulating a hypothetical scenario is necessary since the aim is to assess the effects of allowing the inflation-induced fiscal drag to operate (i.e. assuming that tax systems are not adjusted to for inflation) while

\footnotetext{
${ }^{15}$ It is also possible, and quite common in some countries, that a particular union would negotiate different wage settlements for different wage levels. Nonetheless, the question remains how preferences would be aggregated over employees in each group.
} 
three of the countries considered here do in fact automatically adjust most tax policy parameters for inflation (Finland, Netherlands, UK). ${ }^{16}$

Results are reported for an arbitrarily chosen inflation rate of 7\% - sizeable enough for identifying meaningful bracket creep effects (results for other inflation rates, leading to similar conclusions, can be obtained from the author). Using results from the literature on the elasticity of wages with respect to average and marginal tax rates as a starting point, I then discuss how the measured tax-rate changes may be used to obtain an indication of the potential wage pressures caused by inflation-induced tax-burden changes.

It should be noted that, rather than providing a realistic account of how inflation affects prices and quantities, a uniform increase of all incomes is used here as an analytical tool in order to isolate the effects of "pure" inflation, i.e. a general price increase with constant relative prices. Keeping all other individual characteristics unchanged amounts to the assumption that all prices and wages move in parallel and that taxpayers do not re-arrange their portfolios in response to inflation. Moreover, the scenario rules out changes to income reporting behaviour (which may result from actual changes of real gross incomes, or because higher nominal incomes, and the higher marginal tax rates associated with them, lead taxpayers to report less; Saez, 2003, provides estimates on these latter effects in the United States). While there are good theoretical reasons to take these aspects into account, there is little empirical basis for doing so. Abstracting from transmission issues, it is possible to focus attention on the mechanical links between "pure" inflation and effective tax rates.

\section{Tax-benefit model and data}

The specific model used in this paper is EUROMOD, an integrated European tax-benefit model currently covering the 15 EU countries prior to the 2004 enlargement. The model is designed to examine, within a consistent comparative framework, the impact of national policies on national populations or the differential impact of co-ordinated European policy on individual Member States. Within the context of the present paper, the most relevant feature of the model is that it can produce conceptually consistent and

\footnotetext{
${ }^{16}$ The precise adjustment mechanisms are described in Immervoll (2005) which includes an analysis of the remaining inflation-induced tax distortions in countries operating automatic, but incomplete, inflation adjustment regimes.
} 
comparable output across countries. EUROMOD is built around separate but partly harmonised household datasets describing the population of each country. Using detailed algorithms representing existing tax and benefit legislation, the model is able to compute a range of tax and benefit amounts for each observation unit. These algorithms capture the full range of institutional features including, for instance, accurate income definitions (such as taxable income or the "means" relevant for computing means-tested benefits), definitions of family and assessment units (such as who counts as a child for the purpose of particular tax or benefit rules), thresholds, floors, ceilings and relevant tax rates as well as specific eligibility rules, claw-back rates or income disregards used in computing benefit entitlements. This level of detail makes it possible to derive a finely grained picture of tax burdens and how these vary with earnings and individual or family characteristics. Currently, the main policy instruments that are relevant for this paper and can be simulated with EUROMOD are income taxes, mandatory social contributions as well as universal and means-tested social benefits. Income components that are not simulated and are required as an input into the calculation of taxes and benefits are taken directly from the data. These include earnings and capital income. Further information on EUROMOD and the simulated tax-benefit instruments, including simulation details as well as validation of model results against other sources, is provided by Sutherland (2001) as well as on the Internet at www.iser.essex.ac.uk/msu/emod.php.

Simulations are run for four countries for which EUROMOD modules were available at the start of this project: Finland, Ireland, the Netherlands and the UK. The micro-data underlying the simulations are derived from the 1996 Finnish Income Distribution Survey (IDS), the Living in Ireland Survey, 1994 (Wave 1), the 1996 wave of the Dutch SocioEconomic Panel (SEP) and the UK 1995/6 Family Expenditure Survey. In each case, the samples are weighted to adjust for non-response bias and to bring the results up to population levels. The simulations are based on the systems of tax and benefit rules current in June 1998 and all monetary variables in the micro-data are brought forward to this year using an appropriate uprating index for each type of income (explained in detail in Sutherland, 2001).

Definition of tax rates 
A small "margin" of $+3 \%$ is used for computing marginal tax rates (corresponding approximately to one additional working hour per week for a full-time employee). In other words, the METR represents the fraction of a small earnings increase of $3 \%$ that is effectively "taxed away" as a result of higher taxes and any reduced benefit entitlements.

AETRs, $\tau_{a}$, and METRs, $\tau_{m}$, are thus computed as follows.

$$
\begin{aligned}
& \tau_{a}=(T-B) / E \\
& \tau_{m}=\Delta(T-B) / \Delta E
\end{aligned}
$$

where $T$ is the sum of income taxes and own social contributions, $B$ is the sum of all benefit payments and $E$ is gross employment income. ${ }^{17}$

AETRs and METRs are computed for all employees in the data, where "employee" is defined as a person of any age working more than 10 hours per week and whose employment income represents the main source of earnings (i.e. it exceeds the value of any transfers or incomes from self-employment). Tax rates are measured at the individual level. This means that one needs to decide sharing rules for instruments that operate at a level other than the individual. For example, family benefits are paid to the family as a whole but as a negative tax they potentially influence effective tax rates of each person in the family. In the simulations I make the assumption that all social benefits that do not clearly accrue to one specific person are shared equally among all adults in the relevant family unit. Any taxes that are paid jointly are assumed to be split in proportion to the tax base of each individual of the tax unit (this is important in Ireland, where there is joint income taxation for married couples).

\section{Simulation Results}

The resulting distributions of METRs and AETRs for employees are presented in Figures 2 and 3. The distribution of marginal rates is more concentrated in the UK than in the other countries. Ireland shows the widest dispersion of rates. Table 1 shows that at $33 \%$, METRs are lowest in the UK on average (first column) followed by Ireland and the Netherlands. They are highest in Finland. Turning to average rates (Figure 3 and second

\footnotetext{
${ }^{17}$ The focus here is on the taxes paid on employment incomes E. However, where other income components (such as capital income) are taxed jointly with earnings, taxes are first determined for taxable
} 
column of Table 1), one finds again a relatively pronounced contrast between Finland and other countries. Most Finnish employees are faced with effective tax rates of between 30$35 \%$. More than a quarter face AETRs above 35\% whereas in the other countries, this is only true for a much smaller minority $(0.5 \%$ in the UK, $3 \%$ in Ireland and $9 \%$ in the Netherlands).

\section{[TABLE 1 ABOUT HERE]}

Although it would be interesting to explore these results further, the main interest here is how inflation can cause these rates to change in an unadjusted tax system (a detailed discussion of distributions and driving factors of effective tax rates in $15 \mathrm{EU}$ countries can be found in Immervoll, 2004). In a progressive tax system, one would expect inflation to cause increases in average tax rates for most taxpayers: their tax burdens will increase because of eroded deductions, tax credits and tax band limits. On the other hand, marginal tax rates will only increase for those "slipping" across the upper limit of their current tax band. In a large number of cases taxpayers will remain in the same tax bracket but will be confronted with higher average rates. In these cases, the theoretical and empirical results discussed above would point towards increasing real labour costs. Whether and to what extent inflation raises marginal tax rates for a significant number of tax payers depends on the inflation rate and the proximity of taxpayers' nominal incomes to the next higher tax band limit. An increase in marginal rates will obviously be more likely if tax bands are narrow or inflation is high. ${ }^{18}$ The tax bands of the countries considered here are rather wide. In most cases, one would therefore expect the number of taxpayers with unchanged marginal tax rates to dominate in cases of low to moderate inflation.

\section{[FIGURES 2 and 3 ABOUT HERE]}

This confirmed by the results reported in the last two columns of Table 1 . The fiscal drag caused by uniformly rising incomes has a much bigger effect on average tax burdens than on marginal rates. Indeed, with AETRs, and therefore total tax burdens on earnings, going up by between $4 \%$ and $6 \%$, fiscal drag has a substantial impact on both household incomes and real tax revenues. Figure 5 shows that AETRs go up for almost everybody.

\footnotetext{
income as a whole and then attributed to earnings $E$ in proportion to their overall share in taxable income.

${ }^{18}$ For tax schedules such as in Germany, where the marginal tax rate rises continuously rather than in steps, most taxpayers will face higher marginal tax rates as a result of rising nominal incomes.
} 
In most cases, any negative influence on AETRs, which may result from regressive social contribution systems, less than compensates for the rise in income tax burdens. At the same time, the majority of employees see unchanged METRs in Finland (68\%), the Netherlands $(60 \%)$ and the UK $(85 \%)$. This is shown in Figure 4. The fraction of employees with constant METRs is smaller in Ireland (42\%). Interestingly, we also see reduced METRs for a small number of employees. This can result from upper contribution limits built into social insurance contribution schedules. In addition, as nominal incomes rise, some individuals are no longer eligible for tax credits or benefit payments that are subject to an income taper. They are thus no longer affected by the high withdrawal rates caused by theses benefit claw-backs.

\section{[FIGURES 4 and 5 ABOUT HERE]}

Despite a very steep income tax schedule, a larger fraction of employees in the Netherlands benefit from decreasing AETRs (and METRs) than in other countries. ${ }^{19}$ In Finland the federal income tax is also quite progressive with the largest number of tax bands (six plus a zero-rate band) of the countries considered here. There are no upper contribution limits in Finland and one element (health insurance) actually exhibits a progressive rate structure. As a result, large numbers of employees are confronted with METR increases in excess of 5\%. However, the largest part of total tax revenue (roughly $73 \%$ in 1998 according to Statistics Finland) is generated by local income taxes which operate on a proportional tariff, which reduces the overall increase of AETRs. In Ireland, a large number of taxpayers are at the upper end of the income tax schedule (which consists of only two tax bands with marginal rates of $24 \%$ and $46 \%$ respectively). Given their higher marginal tax rates, the inflation-induced erosion of deductions has a larger effect on their AETRs. In addition, many employees have income just below the upper limit of the lower income tax band. Consequently, bracket creep from the lower to the upper band has a larger effect than in other countries. Taken together, these effects account for the large number of employees facing an increase in their average tax rate of more than 5\%. The bracket-creep effect also causes very substantial METRs increases

\footnotetext{
${ }^{19}$ This is because the regressive social insurance contributions are considerably more important than income taxes in terms of total revenue collected in the Netherlands. They are also much more regressive than in other countries. Employee and employer health insurance contributions are no longer payable at all once employment income exceeds a certain upper limit as higher-earning employees are expected to find private health insurance. See Immervoll (2005) for a description of relevant Dutch and British income tax
} 
$(>40 \%)$ for a considerable number of taxpayers. In the UK, where tax bands are wide, the fraction of employees with unchanged METRs is much higher than in the other countries.

If, as is assumed in this paper, benefit payments are not adjusted for inflation either, AETRs also increase as the real value of benefit payments is eroded. ${ }^{20}$ Family benefits have the largest impact in this respect: around 52\% of Irish and $44 \%$ of Finnish employees live in families entitled to these benefits. In the Netherlands $(40 \%)$ and the UK $(34 \%)$ the fractions are lower. METRs are only by benefit payments if they are incomerelated. In this case, inflation can push individuals out of the income range where benefits are withdrawn. As withdrawal rates are often very high, METRs can decline substantially for the individuals concerned (METRs can drop all the way to zero if the incomes of those originally entitled to means-tested benefits are below the tax threshold). However, this mechanism will only be relevant for a minority of employees as most of them have incomes that make them ineligible for means-tested benefits even in the "before inflation" scenario.

In 1998, around 7\% of UK employees working more than 10 hours received means tested benefits (Income Support, Housing Benefit, Council Tax Benefit). A further 3\% benefited from the income (and working-hours) dependent in-work benefit (Family Credit). As a result, we see relatively large numbers of employees with decreasing marginal rates in. In the Netherlands, about $1 \%$ and $4 \%$ of employees are, respectively, in receipt of social assistance and rent subsidy. The fraction of Irish and Finnish employees receiving income-related benefits (Family Income Supplement and Social Assistance, respectively) is below $1 \%$.

\section{Interpretation and Discussion}

Empirical results on the responsiveness of wage levels to changes in average and marginal tax rates are available for three of the countries covered in this paper. These are presented in Table 2. Studies for all three countries confirm the theoretical predictions of

\footnotetext{
and contribution rules.

${ }^{20}$ In order to capture the pure "bracket creep" effect due to unadjusted income tax and social insurance contribution rules, simulations were also run for a scenario where all benefit rules are indexed for inflation. These results are not reported here but are available on request. Essentially, adjusting benefit rules reduces changes of both AETRs and METRs but differences turn out to be small.
} 
a positive wage effect of average tax rates (a negative elasticity with respect to $1-\tau_{a}$ ) and a wage-moderating effect of marginal tax rates (a positive elasticity with respect to $1-\tau_{m}$ ).

\section{[TABLE 2 ABOUT HERE]}

How might these results be combined with the detailed tax-rate information, presented in the previous section? Unfortunately, there is no straightforward way to do this. Empirically, the main problem is that the elasticities shown in Table 2 are not available at the same disaggregated level as the above tax rates. The studies cited in the notes to Table 2 use a representative agent framework. In this setup, the variation in tax rates, required for an empirical identification of links between tax rates and wage outcomes, is measured for one representative worker only. The typical approach taken to estimate the wage equations starts with the assumption of a non-segmented labour market where there is only one relevant distribution of tax rates (or the distributions are the same in all unions). It is therefore not necessary to identify who belongs to which union. Secondly, the union is assumed to base its target wage on the tax rates faced by an employee with average earnings living in a household that is considered to be "typical". ${ }^{21}$ Hence, there is no need to specify an explicit aggregation rule for the target wages of different union members. ${ }^{22}$

Put differently, the currently available elasticities of wages with respect to marginal and average tax rates do not support the level of disaggregation at which changes in AETRs and METRs have been computed here. Since the bracket creep phenomenon increases tax burdens for practically everybody, the degree of tax-rate heterogeneity is clearly less of an issue than in the case of redistributive tax reforms with large differences between gainers and losers. Nevertheless, the calculations show that the spread of tax rates (and changes thereof) is considerable. This highlights the need to go beyond aggregate studies relying on single representative individuals. By providing detailed estimates of tax rates on an individual level, microsimulation models can be used to enrich the specification of micro-econometric studies of wage-setting behaviour. ${ }^{23}$ This seems necessary to gain a

\footnotetext{
${ }^{21}$ For instance Lockwood and Manning (1993).

${ }^{22}$ See Booth (1985), Oswald (1982) and Oswald (1985) for discussions of different aggregation rules.

${ }^{23}$ Numerous studies examining the role of tax-benefit systems in labour supply decisions have successfully done this. See for example Blundell, et al. (2000), Callan (2000), Callan and Van Soest (1993) and Duncan and Weeks (1997).
} 
better understanding of wage-setting processes in segmented labour markets. Even looking at a single trade union, "members have different labour and non-labour incomes, different family characteristics, etc. and face different marginal and average tax rates [...] The empirical studies of tax effects on wage formation normally use aggregate time-series and do not allow for the microeconomic diversity that microeconometricians would like to emphasize." (Christiansen, 1997: 260)

Using currently available results on the responsiveness of wages, one can merely speculate about the extent of any inflation-induced cost-push effects. One possible scenario is reported in the third column of Table 2. In line with the empirical wage elasticities, they are based on the assumption of a non-segmented labour market. In addition, I assume that unions based their target wages on mean AETRs and METRs so that the change in mean tax rates would be the parameter that drives the union's target wage. The resulting real wage increases of between $0.6 \%$ and $1.6 \%$ suggest that inflationinduced distortions of tax systems do indeed cause cost-push effects through real wage increases. Relative to an inflation rate of $7 \%$, real wage increases in excess of $1 \%$ can be expected to cause some concern, particularly if they are the result of fiscal mechanisms that are meant to act as an automatic stabiliser.

For reasons stated above, however, these numbers are subject to a number of qualifications. More research is needed to understand how disaggregated tax-rate information as presented here can be used to deepen our understanding of wage-setting processes of different groups of employees and in situations where unions represent a heterogeneous membership. Indeed, one would expect the wage-moderating effect of tax progression to be less important for groups of employees where the degree of unionisation is weak. Lockwood et al. (2000) present an approach that recognises that wage determinants are likely to differ between different groups of workers. Using data for Denmark, they find that effects of tax progressivity on wages vary by income group. However, the tax rate calculations used in that paper are approximations do not account for relevant determinants of tax burdens such as household structure. The use of microsimulation models would provide more accurate tax rate measures and a betterfounded basis for studying the impact of tax burdens on wage determination. By providing detailed tax rate data for the full range of different employment situations, these 
models give researchers the variation needed to identify wage equations for different parts of the labour market. 


\section{Tables and Figures}

Table 1. Mean marginal and average effective tax rates before and after inflation in an unadjusted tax system.

\begin{tabular}{|c|c|c|c|c|}
\hline & \multicolumn{2}{|c|}{1998} & \multicolumn{2}{c|}{ following inflation of $7 \%$} \\
& $\begin{array}{c}\text { mean } \\
\text { METR }\end{array}$ & $\begin{array}{c}\text { mean } \\
\text { AETR }\end{array}$ & $\begin{array}{c}\text { relative change } \\
\text { in mean METRs }\end{array}$ & $\begin{array}{c}\text { relative change } \\
\text { in mean AETRs }\end{array}$ \\
\hline Finland & $50.0 \%$ & $30.2 \%$ & $2.1 \%$ & $5.3 \%$ \\
\hline Ireland & $39.1 \%$ & $21.1 \%$ & $3.4 \%$ & $6.0 \%$ \\
\hline Netherlands & $41.2 \%$ & $23.8 \%$ & $0.2 \%$ & $4.0 \%$ \\
\hline United Kingdom & $33.0 \%$ & $20.1 \%$ & $0.3 \%$ & $4.5 \%$ \\
\hline
\end{tabular}

Source: EUROMOD.

Reported changes assume that the fiscal drag is allowed to operate fully, i.e. in the absence of any offsetting adjustments to tax systems. Changes are relative to 1998 values, not in percentage points.

Table 2. Sensitivity of real wages with respect to marginal and average tax rates.

\begin{tabular}{|c|c|c|c|}
\hline & \multicolumn{2}{|c|}{$\begin{array}{l}\text { Elasticity of real pre-tax wages with } \\
\text { respect to: }{ }^{1}\end{array}$} & \multirow{2}{*}{$\begin{array}{l}\text { predicted cost-push } \\
\text { effect of fiscal drag: } \\
\text { change in real pre- } \\
\text { tax wage }{ }^{2}\end{array}$} \\
\hline & $\begin{array}{l}\text { average retention } \\
\text { ratio }\left(1-\tau_{a}\right)\end{array}$ & $\begin{array}{l}\text { marginal retention } \\
\text { ratio }\left(1-\tau_{m}\right)\end{array}$ & \\
\hline Finland & -1 & +0.3 & $+1.6 \%$ \\
\hline Netherlands & -0.61 & +0.18 & $+0.7 \%$ \\
\hline United Kingdom & {$[-0.64,-1.40]$} & {$[+0.65,+1.40]$} & {$[+0.6 \% ;+1.4 \%]$} \\
\hline
\end{tabular}

${ }^{1}$ Sources for reported elasticities are as follows: Finland: Tyrväinen (1995) as reported in Sorensen (1997); Netherlands: Graafland and Huizinga (1996); UK: Lockwood and Manning(1993). No known published studies for Ireland. Where intervals are shown, they represent the maxima and minima of different estimation approaches or measurement periods.

${ }^{2}$ Computed based on changes in mean AETRs and METRs reported in Table 1. 
Figure 1. Changing marginal and average tax rates in a competitive labour market.

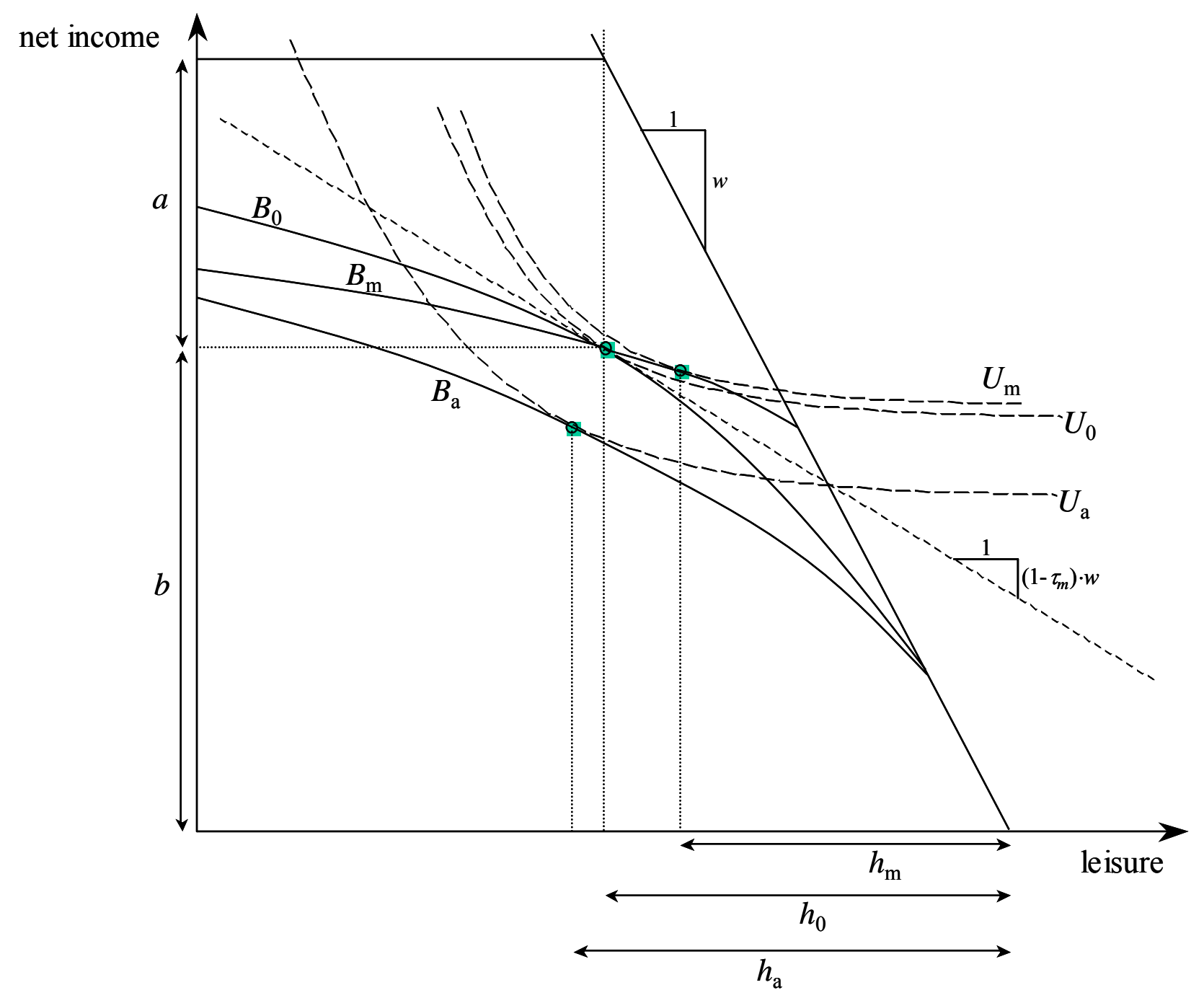


Figure 2. Distribution of Marginal Effective Tax Rates (Employees)

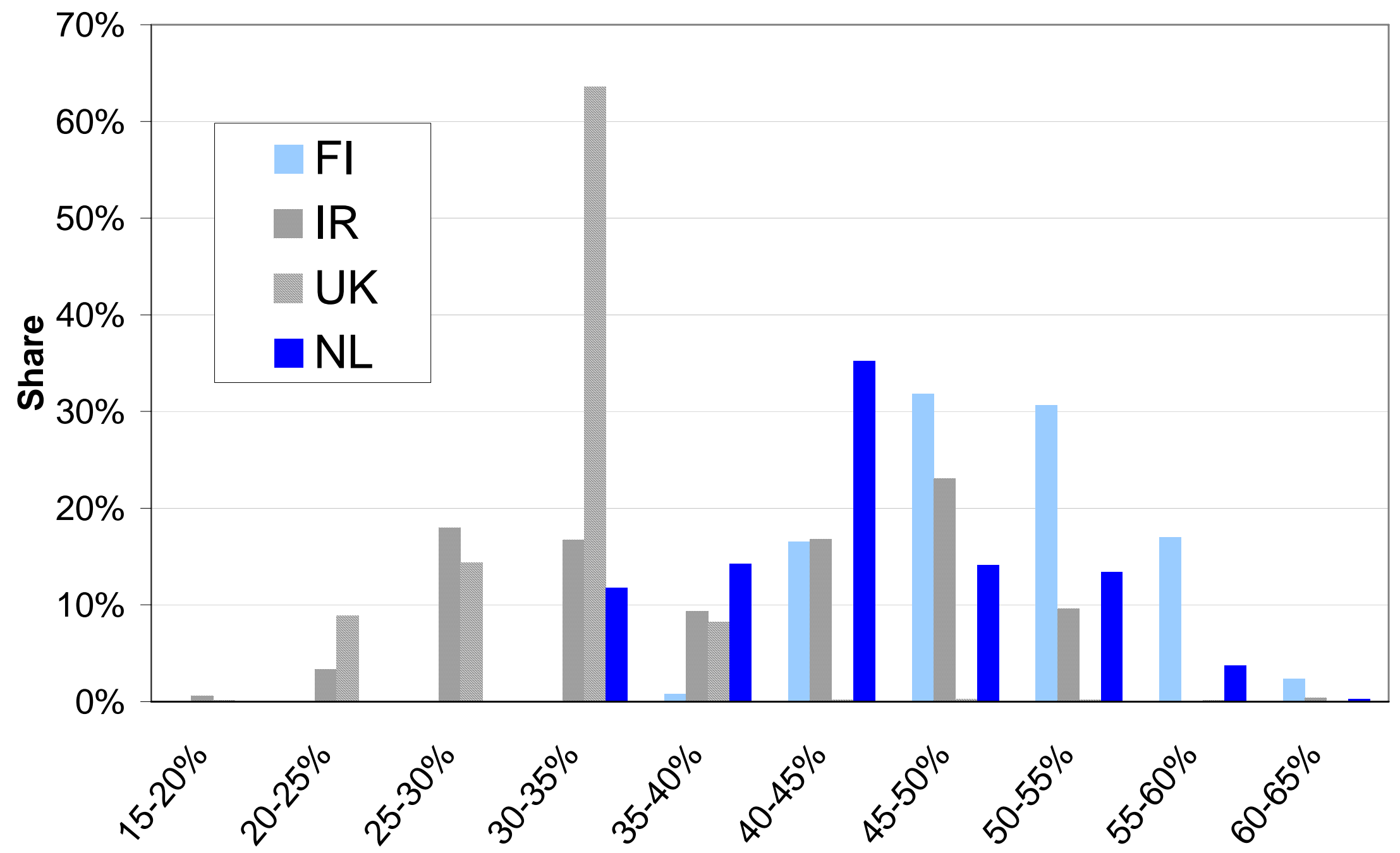

Source: EUROMOD 
Figure 3. Distribution of Average Effective Tax Rates (Employees)

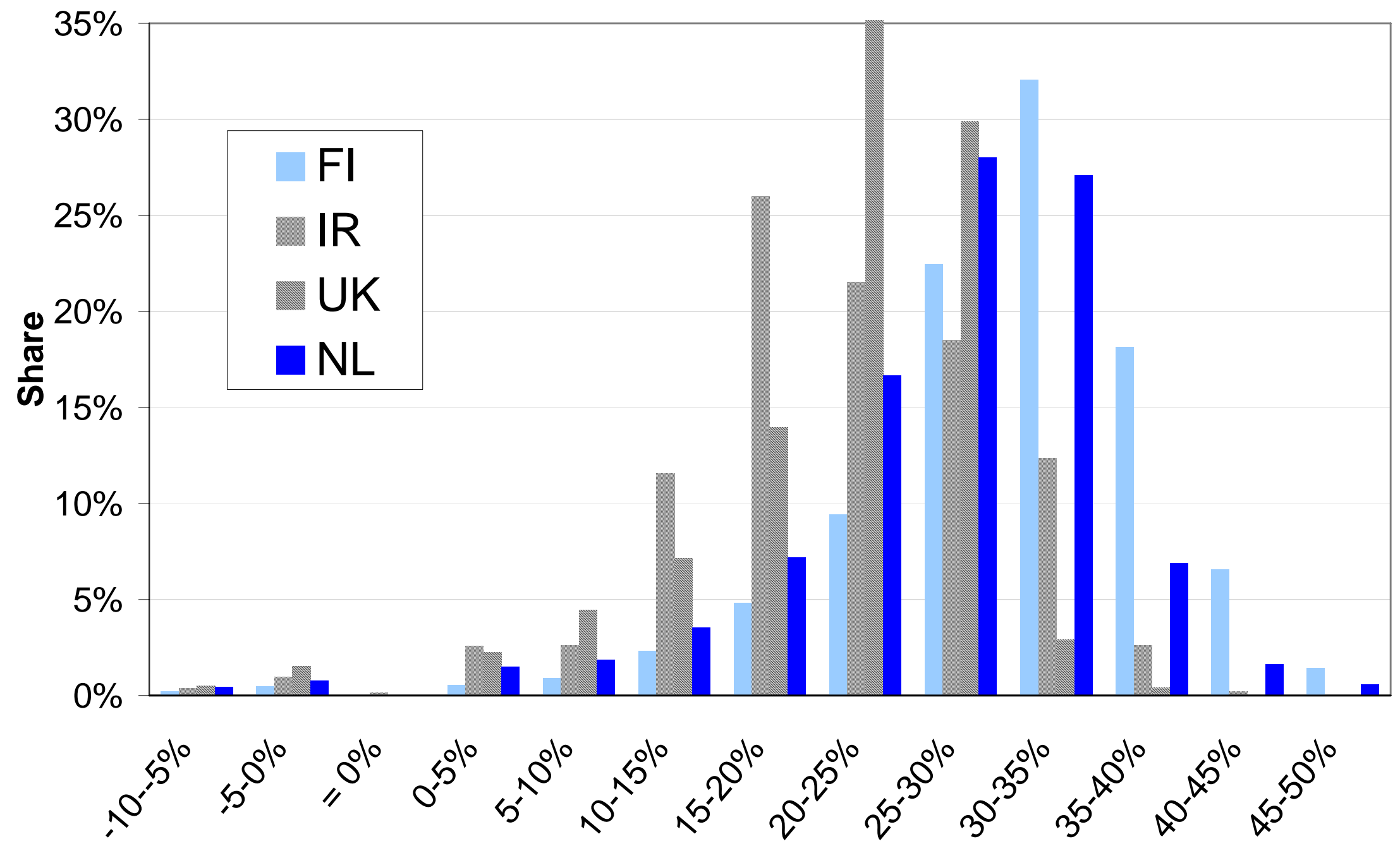

Source: EUROMOD 
Figure 4. Distribution of relative changes in marginal effective tax rates

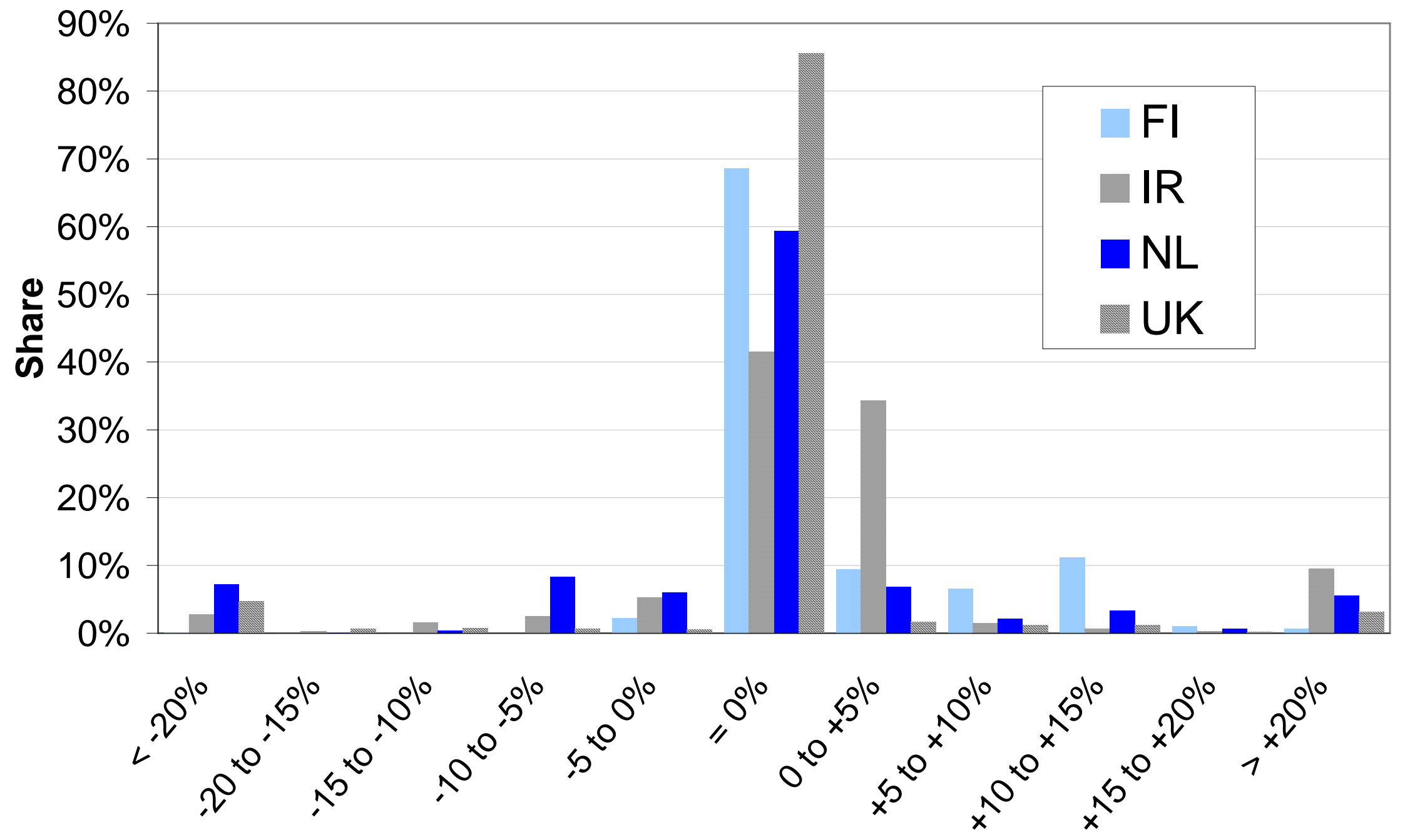

Source: EUROMOD 
Figure 5. Distribution of relative changes in average effective tax rates

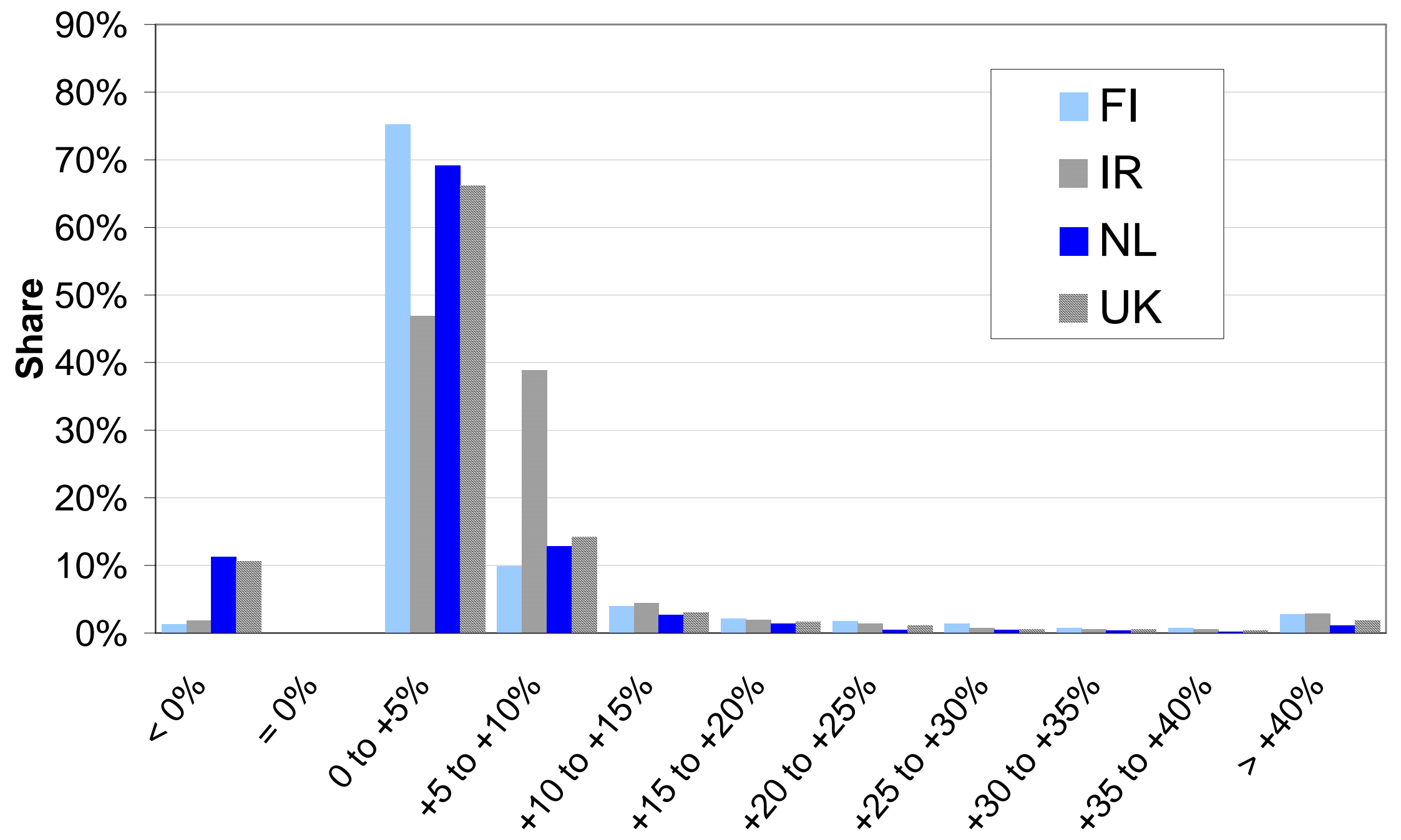

Source: EUROMOD 


\section{References}

Aaron H J, 1976, Inflation and the Income Tax, Washington, D.C.: Brookings Institution.

Andersen T M and B S Rasmussen, 1999, "Effort, taxation and unemployment", Economics Letters, 62, pp. 97-103.

Aronsson, T and T Sjögren, 2004, "Is the optimal labor income tax progressive in a unionized economy?", Scandinavian Journal of Economics, 106, pp. 661-75.

Aronsson T, M Wikström and R Brännlund, 1997, "Wage determination under non-linear taxes: Estimation and an application to panel data", Oxford Economic Papers, 49, pp. 404-18.

Arrazola M, J de Hevia and J F Sanz, 2000, "More on tax perception and labour supply: the Spanish case", Economics Letters, 67, pp. 15-21.

Blanchard, O and L F Katz, "Wage dynamics: reconciling theory and evidence", American Economic Review, Papers and Proceedings, 89, pp. 69-74.

Blinder A S, 1973, "Can income tax increases be inflationary? An expository note", National Tax Journal, pp. 295-301.

Blundell R, A Duncan, J McCrae and C Meghir, 2000, "The Labour Market Impact of the Working Families" Tax Credit", Fiscal Studies, 21, pp. 75-100.

Booth A L, 1985, "The free rider problem and a social custom model of trade union membership", Quarterly Journal of Economics, 100, pp. 253-61.

Brunila A, M Buti and $J$ in 't Veld, 2003, "Fiscal policy in Europe: How effective are automatic stabilisers?", Empirica, 30, pp. 1-24.

Cahuc, P and A Zylberberg, 2004, Labor Economics, MIT Press, Cambridge, Massachussetts.

Callan T and A Van Soest, 1993, "Female labour supply in farm households", The Economic and Social Review, 24, pp. 313-34.

Callan T (ed.) 2000, Taxes, transfers and labour market responses: What can microsimulation tell us?, Dublin: Economic and Social Research Institute.

Christiansen V, 1997, "'Discussion" in Public finance solutions to the European unemployment problem?" Economic Policy, 25, pp. 223-64.

Dernburg T F, 1974, "The macroeconomic implications of wage retaliation against higher taxation", IMF Staff Papers (Nov.).

Duncan A and M Weeks, 1997, "Behavioural Tax Microsimulation with Finite Hours Choices", European Economic Review, 41, pp. 619-26.

European Commission, 1999, "Study 4: Market Integration and Differences in Price Levels Between EU Member States", in: Commission E (ed.), EU Economy: 1999 Review, Brussels.

Fuest C and B Huber, 2000, "Is tax progression really good for employment? A model with endogenous hours of work", Labour Economics, 7, pp. 79-93.

Graafland J J and F H Huizinga, 1996, "Taxes and benefits in a non-linear wage equation", Research Memorandum, 126.

Hansen C T, 1999, "Lower tax progression, longer hours and higher wages", Scandinavian Journal of Economics, 101, pp. 49-65.

Hansen C T, L H Pedersen and T Slok, 2000, "Ambiguous effects of tax progressivity theory and Danish evidence", Labour Economics, 7 (335-47).

Heinemann, F, 2001, "After the death of inflation: Will fiscal drag survive?", Fiscal Studies, 22, pp. 527-46.

Hersoug T, 1984, "Union wage responses to tax changes", Oxford Economic Papers, 36, pp. 37-51. 
Holmlund B and A S Kolm, 1995, "Progressive taxation, wage setting and unemployment - theory and Swedish evidence", Tax Reform Evaluation Report, 15.

Immervoll H, 2005, "Falling up the stairs: The effects of "bracket creep" on household incomes." Review of Income and Wealth, 151 (1), pp. 37-62.

Immervoll H, 2004, " Average and Marginal Effective Tax Rates Facing Workers in the EU: A Micro-Level Analysis of Levels, Distributions and Driving Factors", OECD Social, Employment and Migration Working Paper No. 19, available through www.oecd.org/els/workingpapers.

Immervoll H, C O”Donoghue and H Sutherland, 1999, "An Introduction to EUROMOD", EUROMOD Working Paper EM0/99, available through www.iser.essex.ac.uk/msu/emod.php.

Jackson D, F Wilkinson and H A Turner, 1972, Do trade unions cause inflation?, Cambridge: Cambridge University Press.

Koskela E, 2001, "Labour Taxation and Employment in Trade Union Models: A Partial Survey", Bank of Finland Discussion Paper, 19.

Lockwood B and A Manning, 1993, "Wage setting and the tax system. Theory and evidence for the United Kingdom", Journal of Public Economics, 52, pp. 1-29.

Lockwood B, T Sløk and T Tranæs, 2000, "Progressive taxation and wage setting: Some evidence for Denmark", Scandinavian Journal of Economics, 102, pp. 707-23.

Malcomson J M and N Sartor, 1987, "Tax push inflation in a unionized labour market", European Economic Review, 31, pp. 1581-96.

Messere K (ed.) 1998, The Tax System in Industrialized Countries, Oxford: Oxford University Press.

Musgrave R and P B Musgrave, 1976, Public Finance in Theory and Practice, 2nd Edition, New York: McGraw-Hill.

Nowotny E, 1980, "Inflation and Taxation: Reviewing the Macroeconomic Issues", Journal of Economic Literature, 18, pp. 1025-49.

OECD, 1976, The Adjustment of Personal Income Tax Systems for Inflation, Paris. , 1986, Personal Income Tax Systems Under Changing Economic Conditions, Paris.

Oswald A J, 1982, "The microeconomic theory of the trade union", Economic Journal, 92, pp. 269-83.

1985, "The economic theory of trade unions: An introductory survey", Scandinavian Journal of Economics, 87, pp. 160-93.

Piltz D J, 1977, "Deutscher Landesbericht", in: Association I F (ed.), Studies on International Fiscal Law: Inflation and Taxation, Vienna, pp. 161-79.

Pissarides C A, 1998, "The impact of employment tax cuts on unemployment and wages; The role of unemployment benefits and tax structure", European Economic Review, 42, pp. 155-83.

Røed, K and S Strøm, 2002, "Progressive taxes and the labour market: Is the trade-off between equality and efficiency inevitable?", Journal of Economic Surveys, 16, pp. 77-110.

Saez, E, 2003, " The effect of marginal tax rates on income: a panel study of "bracket creep'", Journal of Public Economics, 87, pp. 1231-58.

Smyth D J, 1983, "Taxes and Inflation", in: Schmukler N and E Marcus (eds.), Inflation Through the Ages: Economic, Social, Psychological and Historical Aspects, New York: Brooklyn College Press, pp. 326-39.

Sorensen P B, 1997, "Public finance solutions to the European unemployment problem?" Economic Policy, 25. 
Sutherland H, 2001, "Final Report. EUROMOD: An integrated European benefit-tax model", EUROMOD Working Paper EM9/01, available through www.iser.essex.ac.uk/msu/emod.php.

Tanzi V, 1980, Inflation and the personal income tax: An international perspective, Cambridge: Cambridge University Press.

Tarling R and F Wilkinson, 1985, "Mark-up pricing, inflation and distributional shares: a note", Cambridge Journal of Economics, 9, pp. 179-85.

Tyrväinen T, 1995, "Real wage resistance and unemployment: multivariate analysis of cointegrating relations in 10 OECD countries", OECD Job Study Working Paper, 10 .

Wulfsberg, F, 1996, " "Do Progressive Taxes Reduce Wage Pressure? Panel Data Evidence from Norway", Memorandum 38/96, Department of Economics, University of Oslo.

Zilberfarb B Z, 1981, "Partial Tax Indexation and Economic Stability", in: Flanders J M and A Razin (eds.), Development in an inflationary world Proceedings of the 1979 Pinhas Sapir Conference, New York, pp. 163-71. 